\title{
Political Martyrdom at the English College in Rome
}

\author{
Howard B. Norland
}

Although martyrdom had been a popular subject in medieval England as attested by the widespread distribution of The Golden Legend and the frequent performance of saints' plays, it took on a new life in the sixteenth century with the Reformation. John Bale, a former Carmelite prior who married and became a prolific Protestant playwright as well as a controversial religious author, may have stimulated an interest in martyrs by his collection of Wycliffite martyrologies and publication in 1574 in Marburg of 'The Examination of Anne Askew', an account of the only woman to be tortured in the Tower of London and then burned at the stake as a heretic in 1546. Bale returned to England in 1547 after the accession of Edward VI and resumed his role as a religious controversialist, but he was forced to leave England again at Queen Mary's accession. Narrowly escaping arrest, he fled to the Netherlands and then on to Switzerland, where he settled in Basel during Mary's reign. He returned again to England after Elizabeth's accession and died there in 1563 .

However, it was John Foxe who became the major spokesman of Protestant martyrology. He began his account of martyrs in 1559 in Latin, but in 1563 he chose English for his Acts and Monuments, which was expanded in six subsequent editions over the next fifty years. ${ }^{1}$ Although Foxe's magnum opus sought to include Christian martyrs of the early Church, its focus remained on the martyrs of the sixteenth century, some 284 of whom were killed during Mary's reign ${ }^{2}$ as well as 63 who had been executed during Henry's rule. Probably the most famous were the Oxford martyrs - Latimer, Ridley and Cranmerwho were burnt at the stake in 1555 and 1556. Tried as heretics, these victims are described in detail from arrest to execution in the commentary on the published text. The emphasis on the physical suffering in the commentary is graphically portrayed in the accompanying woodcuts. Being burned at the

1 For the texts of the versions of John Foxe's martyrology, see http://www.johnfoxe.org/index .php. On its relevance see, for instance, John N. King, John Foxe's Book of Martyrs and Early Modern Print Culture (Cambridge: Cambridge University Press, 2006); William Haller, Elect Nation: The Meaning and Relevance of John Foxe's 'Book of Martyrs' (New York: Harper and Row, 1963).

2 John Foxe claimed there were 300 victims of the Marian persecution.

(C) HOWARD B. NORLAND, 2016 | DOI: 10.1163/9789004323421_006

This is an open access article distributed under the terms of the CC-BY-NC License. 
stake and then drawn and quartered was a fate suffered by many of the declared heretics; the effect of course created an intense hatred and fear of Catholicism, which was compounded by plots and rumors throughout Elizabeth's reign and that of her Stuart successor, James I: the Northern Rebellion in 1569, followed by the St. Bartholomew Day massacre of Huguenots in Paris in 1572, the Babington plot in 1586, and the Spanish Armada in 1588, but most threatening of all, the Gunpowder Plot in 1605. In 1606 the Oath of Allegiance to James I was required of all subjects in the kingdom. It further specified that the pope had no authority to depose a king or to authorize a foreign prince to invade the kingdom, nor did the pope have the power to absolve any subject from subscribing to this oath. In 1606 this was the context of religious conflict-with many political implications - from the Protestant perspective at the beginning of the seventeenth century.

The Catholic view was very different. The martyrdom of Catholics extended periodically from 1534, when Henry viII declared his independence from Rome and assumed the role as head of the English Church, until 1680 according to Catholic records. After Mary acceded to the throne in 1553, following the Protestant reign of Edward VI, she sought to re-establish Catholicism, and the pope appointed Reginald Pole as the Archbishop of Canterbury, who became the leader of the anti-Reformation movement in England. Nicholas Harpsfield became a major spokesman for the Catholic cause after Mary's death and plots to restore Catholicism in England implied a major change in the government involving, not only a change in the monarch, but also in the succession. At its base it was treasonous, as the Protestant government realized. That is the central difference between the Catholic martyrs and the Protestants who were viewed as heretics. The Catholics in the kingdom were viewed as the enemy within, a kind of Fifth Column that was most dangerous because it depended on secrecy and deception. For Elizabeth and her ministers, as well as her successors, the Oath of Allegiance and the Oath of Succession were the bulwark determined to protect the monarch's person and his/her rule.

The creation of Catholic colleges for English recusants in various towns and countries in Europe posed a threat with serious implications for the Protestant societies, particularly in northern Europe. The immediate danger to England must have been recognized as the colleges of Douai and St. Omer became popular training sites for English boys; they were the closest and most accessible for Catholic families who had not accepted the new English Church, though some boys found their ways to colleges, many operated by the Society of Jesus, as far away as Prague, the Iberian peninsula, and Rome. The English College in Rome was founded in 1580 with fifty students, a number that later increased to seventy-five, and like other colleges of its kind, it soon began producing plays. 
Though 'not constitutionally Jesuit, it followed the regulations of the Ratio studiorum only as far as the rector might dictate', as Suzanne Gossett points out. ${ }^{3}$ This allowed for some individual interpretation of the rules. Several of the plays performed at the college had already been put on at St. Omer, a common practice among the Jesuit schools, although some were apparently written by members of the faculty where the plays were performed. This seems to be the case for the three martyr plays we shall examine, Thomas Morus, Thomas Cantuarensis, and Roffensis, commemorating Henry vin's celebrated Lord Chancellor, Thomas More, the much loved Archbishop of Canterbury under Henry II, Thomas Becket, and the revered Bishop of Rochester, John Fisher. ${ }^{4}$ All three plays appear to have been written for performance at Carnival, and all three are anonymous; whether they were written by the same author or by two or three authors has not been determined, ${ }^{5}$ but the attitude toward the secular power expressed in them is consistent.

\section{Thomas Morus}

Performed at the English College in Rome in 1612 according to the preserved manuscript in the college archives, Thomas Morus is said at the end of the text to have been 'thrice given, always pleased.' In fact, according to the records, it appears to have been performed at least six times during Carnival of $1612 .{ }^{6}$ The choice of subject was perhaps natural since More was one of the most popular English Catholic heroes on record, and his grandson may have been a student at the English College at that time. Also, a play entitled Sir Thomas More, written in English and designed for public theater performance in England, had been prepared and submitted to the official censor, Edmund Tilney, some dozen years earlier. The surviving manuscript, which had been marked for required

3 Suzanne Gosset, 'Drama in the English College, Rome, 1591-166o', English Literary Renaissance 3 (1973), 60-93, esp. p. 62.

4 All three plays, bound with four others performed at the college, are found in Ms English College (Rome), Lib. 321, fols. $2^{\mathrm{r}}-3^{\mathrm{r}}$ (Thomas Morus), $61^{\mathrm{r}}-101^{\mathrm{v}}$ (Thomas Cantuarensis), and

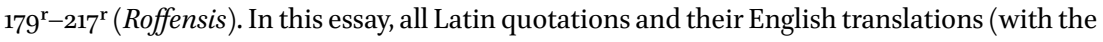
occasional alteration) are taken from Thomas Morus, Thomas Cantuarensis, and Roffensis, ed. by Dana F. Sutton, The Philological Museum (2004, 2005, 2013): http://www.philological.bham .ac.uk.

5 See Gossett, 'Drama in the English College', p. 69, and Sutton, 'Appendix: Overview of English College ms 321'.

6 See Gossett, 'Drama in the English College', p. 91. 
revision, is believed to be the work of at least five authors: Anthony Munday, Henry Chettle, Thomas Heywood, Thomas Dekker, and William Shakespeare. ${ }^{7}$ This play was not published until centuries later, although its existence was known, despite its performance never having been allowed. A comparison of the texts of Sir Thomas More and Thomas Morus does not reveal that the author of the Latin version was aware of the English popular play, but its existence and the requirement of textual revisions point to the controversial nature of the subject matter. In fact, the martyrdom of Thomas More continued to be a sensitive issue because it questioned the power of the king in relation to the Church and prompted the charge of treason. However, a comparison of the two plays throws into bold relief the way in which More was represented for the Protestant popular English audience on the one hand and perceived by the Catholic Church for its audience of candidates for the priesthood and potential martyrdom on the other. More's reputation as a man of the people underlies the character of the protagonist in both plays. In the popular English play More's sense of humor and his appreciation of wit, which he demonstrates on many serious occasions, make him a comic figure that lightens the mood and emphasizes his intelligence as well as his self-control. Thus he emerges as a guide for the audience to evaluate the speech and action of other characters present on stage. In comparison, Thomas More in the Latin Catholic play is not a comic wit per se, although he does on occasion show a flash of humor. Rather, he is a symbol of piety and right judgment, who is courageous and determined to remain true to his faith in spite of pressures from the king, his friends, and his family. His relationship with the king appears to be very strong; clearly Henry viII admires More's character but is frustrated by his refusal to alter his judgment that God's command must come before the king's desire. As a result, Henry is cast as denying God and flouting God's lieutenant on earth, the Pope. Assuming the role as Head of the English Church, Henry is represented as a self-appointed tyrant without authority. By contrast, the English popular play does not question Henry's authority or his right to demand obedience from his subjects. This is not an issue, and Henry vin never appears on stage.

Another significant difference in the two plays is the portrayal of More's relationship to his family and their attitude toward his martyrdom. Well known were Erasmus's letters celebrating More's family for their learning, scholarly discipline, and family devotion that extended to court wards and family friends,

7 For a discussion of this play and its context, see Sir Thomas More, ed. by John Jowett (London: Methuen, 2011). 
Anne Cresacre and Margaret Gyge. ${ }^{8}$ Harpsfield and Stapleton, early apologists for Thomas More, emphasized his particular fondness for them and the very strong bond he had with his eldest daughter, Margaret. Clearly his relationships with the young women in his family were especially noted. ${ }^{9}$ His interest in young women from the perspective of learning and protection, as well as the appropriate selection of marriage partners, was indicated in his correspondence with his friends and family. The English popular play includes More's wife and his daughter Margaret, who was married to William Roper, as well as 'More's other daughter', unspecified by name. In the Latin version performed at the English College in Rome, neither More's wife nor any of his daughters appear. This would have been in accordance with the Jesuit dictum against women roles in college productions. The one More family member cast was More's only son John, who does not appear at all in the English popular version. John has a somewhat questionable reputation. Historically, after More's execution, he signed the necessary allegiance to King Henry viII and was pardoned, but rumors circulated about his intellectual capacity. He did not attend either Oxford or Cambridge and did not enter the Inns of Court for legal training. Erasmus dedicated his commentary on the poem Nux (1523) to him, but John appears to have left no literary heritage.${ }^{10}$ Clearly, he was introduced into the Latin play as a figure with whom the audience of teen-age boys could identify.John's role must not have been an unmitigated success because his part was reduced in a manuscript revision of the play.

The Latin Thomas Morus adopts an old-fashioned image of evil from the morality play in the figure of Cacodemon, who introduces the source of the evil in Henry viII's court; he focuses upon the tyrant's rage, which he encourages and applies to the current situation:

8 On this, see Peter G. Bietenholz and Thomas B. Deutscher, Contemporaries of Erasmus: A Biographical Register of the Renaissance and Reformation, 3 vols. (Toronto: University of Toronto Press, 1985-1987), II, pp. 456-459, where the relevant letters are mentioned.

9 Nicholas Harpsfield, The life and death of Sr Thomas Moore, knight, sometymes Lord high Chancellor of England; a modern edition of the manuscript in William Roper and Nicholas Harpsfield, Lives of Saint Thomas More, ed. by E.E. Reynolds (London: Dent; New York: Dutton, 1963); Thomas Stapleton, Vita Thomae Mori, in id., Tres Thomae (Douai 1588); see also The Life and Illustrious Martyrdom of Sir Thomas More, Formerly Lord Chancellor of England (Part III of "Tres Thomae", printed at Douai, 1588), transl. by Philip E. Hallett (London: Burns Oates and Washbourne, 1928).

$10 \quad$ See P.S. Allen and H.M. Allen, Opus epistolarum Des. Erasmi Roterodami, 12 vols. (Oxford: Oxford University Press, 19o6-1958), v, pp. 363-365, Ep. 1402. On John More see Bietenholz and Deutscher, Contemporaries of Erasmus, II, pp. 454-455 (s.v. John (III) More). 
Invisa exulat,

Sed puritate nobilis, regum genus

Catherina, pellex Anna regalem obtinet

Incesta thalamum, filia an coniux viro

Incerta. Dubia sobole perturbat domum,

Dum sibi sororem parturit, neptim viro.

I.ii, $11.75-80$

(Catherine is in exile, hated but noble for her purity and born of kings, while unchaste Anne, the whore, obtains the royal bedchamber. It is unclear whether she is a daughter or a wife. She throws his household into confusion with her questionable offspring, she gives birth to a sister for herself, a niece for her husband.)

This suggests that Henry is guilty, not only of deserting his lawful wife, but also of committing incest because of his previous affair with Anne's mother. This charge of lustful incest is repeated several times in Catholic propaganda. ${ }^{11}$ Thus Henry is identified at the beginning as the source of the evil in the court and the natural opponent to virtue and goodness, while More becomes the antagonist of tyranny and defender of the Catholic Church. Henry's supportersCromwell, Cranmer, and other corrupt officials in the government - encourage the repeal of the pope's laws and applaud the king's opulence, which will turn the spoils from the closure of the monasteries into rewards for Henry's followers. Although the members of the king's party are not individualized in the play, in Act Iv Henry draws out Cromwell, Cranmer, and Audley, revealing their harsh characterizations of each other-their treachery and disloyalty as well as their hypocrisy. These judges of More, who sentenced him to death, are completely discredited before they reach their verdict.

The preserved manuscript does not reveal much of the music that must have been included in the production but, in a feature characteristic of Catholic college productions, six dancers in pairs provide a distraction from the dialogue (II.iii). The courtiers accompanied by the Chorus liven things up for a

11 The first to suggest this, according to William Camden, was Nicholas Sander in his 1585 De origine ac progressu schismatis Anglicani. The Catholic writers, Nicholas Harpsfield, Reginald Pole, and William Rastell, do not mention it. The issue is discussed by Christopher Highley in "A Pestilent and Seditious Book": Nicholas Sander's Schismatis Anglicani and Catholic Histories of the Reformation', in Paulina Kewes (ed.), The Uses of History in Early Modern England (San Marino, CA: Huntington Library, 2006), pp. 147-167. 
little while, but the final two acts bring the martyrdom of More to an unspectacular end. More and the king's men are at an impasse. When confronted by them, he refuses to endorse the king's will to make Anne his wife and mother of the heir to the throne. Although More begs for compassion because of old age weariness, he is not allowed to avoid the king's demand. To increase the pressure on him, the Bishop of Rochester, John Fisher, is introduced into the play; Rochester proves as adamant as More in refusing to endorse Henry's scheme to reject the pope's role as head of the Church and ignore his refusal to annul Henry's marriage to Catherine. More and Fisher are thus brought together as traitors, and both are sentenced to be executed. They are beheaded within a few days of each other, the audience is told, but the comparison between the two martyrs is inevitable. A short time after Fisher is introduced into the play, he is beheaded and his head placed on a pole, whereas More is represented as meeting his son John for the last time. He chides John for foolishly prating and not living up to his family training, and he instructs him on the importance of virtue, saying: 'Here the turning wheel spins, here too contrary winds do blow. Virtue is the single sure foundation; relying on it, you will stand' ('Versatilis et hic volvitur gyro rota, | Contrarii etiam hic saeviunt venti. Basis | Est una stabilis virtus, hac nixus stabis', III.vi, ll. 1225-1227). John here becomes an example for the seminary students in the audience for occasions when they will encounter a critical situation. Only a few minutes later, the Bishop of Rochester's head is brought onto the stage, and More declares that he will bring his aged body to the blessed scaffold. Joining the martyrdoms together, the author emphasizes the virtue of More, which reaffirms the courage and conviction of Fisher.

The scene in which More meets with the king and his accusers takes the form of a trial as the prosecutor presents the charges and the king's supporters question his responses (Iv.iii). Offering a defense of his actions based on his Catholic beliefs, More explains his intransigence as a demonstration of his Christian faith. He welcomes martyrdom as the price he is willing to pay. When he is sentenced to high treason, a crime punishable by drawing and quartering, he does not blanch, but as an act of mercy it is announced that he will instead be beheaded and his body will be buried. Other signs of pity and respect are introduced but passed over. More links his fate with Fisher at the end of the trial. Before departing, he says: 'Am I to follow pious Rochester? You command. I shall follow wholeheartedly. Let eternal hymns of praise be sung in your honor' ('Pium | Sequar ego Roffensem? Iubes, totus sequar, | Aeterna laudum cantica sonentur tibi', IV.iii, ll. 1664-1666). He refuses to call Henry a tyrant, saying he has followed the bad advice of his counselors, who are now at this trial. The scene nevertheless ends with a mild witticism on More's part. To Cromwell's 
news that Henry has reduced the sentence from hanging to decapitation, More rejoinders: 'at least he is saving work for the hangman' ('Labore nempe carnificem levat', III.iv, l. 1742).

The final act of the play opens with John More complaining about the disappearance of justice and piety, deploring the reign of crime, and appealing to those martyrs who have gone before: 'o you, destined to be member of the sacred company and part of the purple-clad choir of martyrs' ('O tu futurus caetui comes sacro, | Et purpurato martyrum aequalis choro!', v.i, ll. 1810-1812). The disposal of the martyrs' bodies is raised as a practical issue of martyrdom when More returns to the stage on his way to his execution. Although the execution itself is not staged and stories about More's conversation with the hangman and his witticisms at his final critical moments on the scaffold are ignored by the Latin author of the production at the English College in Rome, More does have a witty exchange with two men on the way to his death. A citizen kisses More's hand as repayment for security conferred upon him to befall him in heaven and More answers, 'Let God grant you whatever you wish, such a brave heart never asks for forbidden things' ('Det tibi quaevis Deus, | Tam forte nunquam pectus illicita rogat', v.iii, ll. 1838-1839). This conversation is interrupted by a little merriment. The king's servant, Audley, tells More he has heard that he has changed his mind, to which More replies that indeed he has: 'I had thought to remove the beard from my head, but now beard and head will be discarded together' ('Barba statueram ponere erasum caput, | At barba nunc ponetur et caput simul', v.iii, ll. 1843-1844). Audley takes this as mockery of the king, to which More responds, 'Why should I not joke? Our serene king bids me set aside things I take seriously. I obey, and set aside my head' ('Quid ni iocare? Seria benignus iubet | Princeps remittam. Pareo, demitto caput', v.iii, 1l. 1847-1849). After More has departed from the stage the last time, the Chorus speaks to the grieving John More:

Puer

Miserande nimium. flere nos vices tuae

Possent coegisse, publicae casus rei

Ni postularet quos damus lachrimas tibi.

Non filio tantum perit Morus tuus,

Eripitur Anglia, occidit tibi pater.

v.iii, 11. 1877-1882

(You very piteous boy, your catastrophes could compel us to weep, if the public calamity did not require the tears we are giving for you. Your More did not just die for his son. He is taken from you, but stolen from England.) 
This emphasis on the national calamity that More's martyrdom represents makes John's grieving appear selfish. The martyrdom is not shown in all of its inherent violence but it is rendered in dignity with a touch of More's old wit.

\section{Thomas Cantuariensis}

Just one year later at Carnival of 1613, the English College at Rome performed another martyr play, Thomas Cantuariensis (Thomas of Canterbury), celebrating a most popular English saint, Thomas Becket, Archbishop of Canterbury from 1162 to 1170 . Although the shrine at Canterbury Cathedral had been brutally destroyed in 1538 , along with its relics, on the orders of Henry VIII, Thomas Becket continued to be honored by Catholics in England and was a favorite saint at the English College in Rome. This may help to explain the choice of Thomas Cantuariensis as the follow-up play to Thomas Morus. However, more important, it carried on the conflict between papal authority and secular power, a central issue of the Reformation in England, and also provided an historical mirror of the past that presented a warning of the future. This must have been particularly relevant to the historical context of 1613 when the English were still mourning the loss of Prince Henry, the eldest son of King James, a particularly promising and popular eighteen-year-old heir to the throne. His death on 6 November 1612 left Prince Charles, aged eleven, next in line; however, he was so weak and sickly that parliament passed a bill making Princess Elizabeth, aged thirteen, and her newly married teenaged husband, the Elector Palatine, joint heirs to the English crown should Charles not survive or prove incapable of ruling. The line of succession was a delicate point, and in case James should die, the king's immediate heirs would be children, which suggested instability and political maneuvering in the competition for power. The youthful monarch lacks experience in judging the people and circumstances with which he must deal, and as a result he fails to control the developing action and makes serious errors, as the text of Thomas Cantuariensis illustrates in the person of the Young Henry, the son of Henry II.

The Latin author provides an image of Henry II's court apparently ruled by Henry the Younger, who had been crowned king on June 14, 1170, while Becket was in exile, by his father with the collaboration of the Archbishop of York and Bishops of London and Salisbury, apparently to ensure the succession. However, Henry II is absent when Becket returns to Canterbury, and Young Henry appears to be in charge; in fact, his father never appears in the play. The conflict waged between papal authority and secular power is thus represented by the Young Henry, who is described or identified as a boy several times, 
particularly in the first three acts, usually in relation to his immaturity and vulnerability to evil. As Becket says, 'the Young King's heart is youthful, it is quickly swept to wrath, and, as is youth's way, the emotion he conceives will very soon be set aside' ('Iuvenile regi pectus est, aestu citus | Raptatur irae, quodque iuvenes assolent | Motus quos concipit cito ponet cito', II.iv, ll. 561563). The Earl of Leicester, in a choric speech, responds to Young Henry's refusal to hear Becket's entreaties unless he absolve the bishops who had defied him and whom he excommunicated - in other words, unless he allow the king to dictate the government of the Church as well as the state. Leicester explains the implications:

Quid hoc? Praesulis tanti preces

Aure obstinata respuit iuvenis? Negat

Manum osculandum tendere. O patriae vices!

O sortem acerbam! Fertili a cuius sinu

Tot prodiere principes vere pii

Et Christiani, dispares quantum videt

Surgere nepotes, impios, duros, feros!

Fulsere quondam decore regali, Angliae

Torsere quondam sceptra queis studium fuit

Cleri tueri iura, pontifices ope

Protegere certa, praesules sacri gregis

Quem purpuratus proluit Christi liquor

Honore summo prosequi. Hinc regni decus,

Hinc res secundae plebis, hinc pietas viget.

At nunc sequentes quantus incessit furor!

Quam terminum ultra moris humani tument!

Utinamque finis iste contingat, gradus,

Nec sit futuri nuper admissum scelus.

Nam quanta adultus ista qui fecit puer?

II.iii, ll. 519-573

(What's this? Does the boy scorn so great a prelate's entreaties with a stubborn ear? Does he refuse to hold out his hand for the kissing? Oh our nation's misfortunes! Oh its bitter fate! From its fertile bosom have issued so many truly pious and Christian sovereigns, and how unlike the descendants it sees cropping up, impious, harsh and fierce! Once England's scepters shone when they were wielded by men zealous to protect pontiffs with their assured strength, to attend with the greatest honor on prelates of the holy flock, washed with Christ's ruddy blood. By 
this flourished the realm's glory, by this the people's prosperity, by this piety thrived. But now what madness has overcome their successors! How they are puffed up beyond human limit! And would this were the limit, and not a step further towards future crime! For what great crimes will he commit as an adult, who has done these things as a boy?)

The worry is what the young heir to the throne might be capable of doing as an adult, if he shows such disrespect to the senior Archbishop of the Church in England. The fear that the youthful monarch is leading the state into degradation is an interpretation of the present and a warning for the future if the state is governed by a youthful monarch. In the context of Stuart England, this would mean the case of the country being ruled by the weak, sickly Charles or his sister Elizabeth and her boyish husband.

The Latin author may have found it easier to cast a teenage seminarian as a young king than the fifty-year-old Becket, but this dialogue also served his interpretation very well by inverting the usual relationship of youth and age as the young man holds a superior position to the senior spokesman for the Church. This changes the dimensions of the conflict between secular power and religious authority immensely. However, in Act III the action shifts toward the martyrdom of Becket and its source, which is put squarely in the mouth of the older Henry II. The potential assassins discuss at length the king's wrath provoked by Becket, and Moreville claims the king 'turned to him and said: "Will nobody free me from that man?"' ('Conversus ad me deinde, me nemo ex meis | Liberat ab illo?' III.i, ll. 762-763), referring to Becket; this question supposedly articulated by Henry II has been repeated so often by writers about these events that it is taken to be true. Even though the king does not appear in the Latin play, he is charged with the responsibility for the martyrdom. Young Henry returns to the stage in the following scene with his brother Richard, who provides a choric commentary on Young Henry's response to the Hermit, in actual fact an Angel, who provides a prophetic image of the future. Addressing Young Henry as 'feckless boy' ('puer impotens', III.iii, 1. 897), the Hermit predicts that he and his brothers will rise up against their father: 'the sons will wage wicked wars against their felonious father' ('Scelerata nati bella scelerato inferent | Dira parenti', III.iii, 1l. 926-927). This future family rebellion is perceived as stemming from royal evil, which is punished by providence. The Latin author also uses a supernatural being later, in Act IV, to reassure Becket that although he will suffer martyrdom, the benefits are worth the suffering. There, the Angel explains that 
Sorte felici cades

(Si casus iste transitus dici potest),

Cuius salutem morbidis dabit cinis

Veniam dolenti scelera, solamen bonis,

Durisque presso pectori laetas vices,

Sol Anglicanum lumine illustrans solum

Quacunque puram tellus admittit fidem

Dicere clarus.

IV.ii, ll. 1193-1200

(You will fall by a happy stroke of fate (if that passage can be called fate's stroke), you whose ashes will give health to the ailing, forgiveness for the man who repents his sins, consolation to the good and happy turns of fortune for those with hard-pressed hearts, you will be called a great sun brightening English soil with your light, illuminating wherever the land admits pure faith.)

The Angel then proceeds to prophesy the Reformation, beginning with Wycliffe and continuing with Luther, which produces the martyrdoms of Thomas More, John Fisher, and later Campion, Southwell, Walpole, Garnet, the Roberts, and the Barkworths. Finally, he addresses the audience at the performance in the English College: 'Nor should I pass you by, you Roman youth ... Here you have Sherwins, Harts, Haycocks, Newports. Another Gregory, rival to the Great, will send these.' ('Nec te praeteream, pubes Romana ... | En ibi Sherwinos, Hartos, Hadocos, Neuportos. | Aemulus hos magni mittet Gregorius alter', Iv.ii, ll. 12541255). This direct appeal to the students who were carrying on the mission of the Church by following Becket's example of martyrdom reinforces the purpose of the play. It also prepares the audience for Becket's assassination.

Becket is not murdered on stage, though his death is graphically described; however, it is the way the martyrdom is represented that focuses its meaning. Unlike the executions of More and Fisher, the murder of Becket is unauthorized by government decree; rather, four landowners from southwest England take justice into their own hands as they put loyalty to the king before reverence to the Church. The way in which Becket is killed emphasizes the dishonorable nature of the act. Four armed knights launch a cowardly attack on an unarmed priest in his place of worship, dash his brains out, and then run away. Young Henry, to whom the messenger directs his report, interrupts the account by shouting: 'Oh shameful deed and far more shameful, Henry, will be your name' ('O turpe facinus, turpius longe tuum, | Henrice, nomen!', v.i, ll. 1575-1576), and he accuses himself, a former enemy of Becket, of responsibility for the murder. 
However, it is the assassins themselves who are focused upon in the final act. They are so overcome by their guilt that they expect to be crushed to death for killing the head of the English Church, their father as they call him. When all four assassins lie down awaiting their punishment and then consider suicide, they undergo a strange transformation. Their interpretation of the event is that though they deserved to die, God in His goodness has indulged them with time for penitence and will forgive them. The play ends with their promise to go 'immediately to Rome, to the feet of the supreme pontiff' ('summi protinus Romam ad pedes | Praesulis abibo') and, declares Tracy on behalf of all the assassins, 'I shall endure whatever punishment he appoints' ('criminis paenas dabo, | Quascunque ponet ille', v.ii, ll. 1858-1860). The play thus ends on a note of piety as the promise of forgiveness through penitence triumphs over tragedy.

\section{Roffensis}

The third English martyr play produced at the English College in the second decade of the seventeenth century appears to have followed some five or six years after Thomas Cantuariensis. Although no record of performance has been discovered, it is believed to have been written about 1617-1618. Like the earlier martyr plays, Roffensis, which focuses upon John Fisher, Bishop of Rochester, is anonymous; whether it was written by the same author or authors of the More or Becket plays has not been determined, though it was likely intended for performance at Carnival, as were the others. ${ }^{12}$ Roffensis revisits the reign of Henry ViII that had been the context for the earlier Thomas Morus, and although a number of characters are repeated, including Henry viII and members of his court, a major difference in their character conception is the role they play in the two dramas. More is shown more respect, perhaps as a result of his former position as Lord Chancellor, while Fisher is subject to ridicule, especially at the beginning of Roffensis. However, most significant is the different portrayal of the issues regarding papal authority and royal power.

Personifications of Madness and Heresy provide a prologue for the drama and play a major role throughout the action. Not only do they represent the negative aspects of the court and the state, they become cheer-leaders to stimulate and encourage the divisive elements on the stage. Their constant presence in the court emphasizes the toxic atmosphere at the heart of the government.

12 Suzanne Gosset, in 'English Plays in the English College Archives', The Venerabile 28 (1983), $23^{-} 33$, says there is no evidence that Roffensis was ever actually performed. 
To extend the international implications of the dimensions of the action in England, the Latin author includes a formal chorus representing Rome, England, Spain, and Germany. At the end of each act except the final one, they provide commentary on what they find relevant that is occurring in England. At the end of Act I, the chorus expresses its sympathy for Queen Catherine discarded and deserted by Henry viII who has replaced the queen's piety with the embrace of a whore, but Germany reminds the audience that Charles, the new Caesar, is Catherine's nephew and should grieve for her. Catherine's situation evokes sympathy again after Act II, this time by Spain, but the chorus at the end of Act III focuses more particularly upon Henry. Compared to the archetypal tyrant Nero by Rome, Henry is said to be governed by madness says England, while Spain claims that Henry burns with a blood-thirsty passion, and Germany says he imitates barbaric kings and passions worthy of the Vandals. The fourth and final formal chorus celebrates the martyrdom of Rochester, concluding with the refrain by each member of the chorus: 'He will live, destined to enjoy eternal life' ('Vivet aeterno fruiturus aevo').

Early in the action, the Latin author provides an indication of the papal support of Fisher by a message from Pope Paul announcing that he has been named a cardinal. Called to the sacred purple, Fisher is assured that he has the support of the Church. It is notable that almost immediately after this news, the contrast between Lady Catherine, the former queen, and Henry's new queen, Anne Boleyn, is presented in conventional images of Age and Youth. Although neither woman is shown on stage, in accordance with the Jesuit ban against female actors in the theater, the playwright offers a moment of sympathy for the discarded ageing queen. To signal a change from the melancholic mood to a more lively effect, the chorus arrives on stage where they dance and then come at each other with their weapons drawn, apparently as a warning to King Henry VIII of the violence to come. It is in this context that Henry mentions the incest of moving from a mother's bed to a daughter's, which is an allegation about Henry's relationship with Anne Boleyn's mother before he married Anne. This particular piece of Catholic propaganda had also been expressed in Thomas Morus, as noted above.

Roffensis represents More and Fisher being imprisoned in the Tower at the same time and communicating with each other through messages conveyed by prison staff, though they do appear together on stage a couple of times. They are individually subjected to questioning by the King's men in a similar way: Fisher is told the lie that More has assented to the king's demands, while More is told the lie that Fisher has agreed to the king's remarriage and claim to become head of the English Church. What in fact happens is that neither More nor Fisher believes that the other has deferred to the king's will, both remain 
stalwart in response to the pressures of secular power, and both willingly accept martyrdom as they demonstrate their faith and loyalty to the Church. The similarity of their responses to their inquisitors is also to be noted; their words are described as 'harmonious', and both are said to wish to die together, although in fact they die separately.

Despite these similarities, the treatment of martyrdom in the Roffensis play is very different from that of the earlier Thomas Morus. After being ridiculed in the early part of this play and subjected to the unrelenting pressure of the king's men, Fisher withstands the test admirably. He remains adamant in his faith, declaring as his execution approaches: 'I am compelled to prefer God to my king' ('cogor ut regi Deum | Preferre', Iv.iii, ll. 1411-1412). His defenders as martyrdom nears are Darcy and Musgrave, who as choric commentators evoke sympathy for the old man who appears to be greatly outnumbered in a hostile world. The last act is devoted to the response of the king and his court to the death of Fisher and its effect on members of society. It begins with a sympathetic account of Fisher's fate, is followed by references to Cromwell, that 'creator of evil' ('sceleris artifex', v.i, l. 1691), and closes with Fisher being placed in the tradition of Saints Polycarp, John the Baptist, and Ignatius. However, most startling is the vision the king has of an apparition of a monster, which is described in detail and was perhaps intended to be seen by the audience. Finally, Walsingham appears on the stage bearing Fisher's head (v.iv). Henry notes its 'ancient bloom' and 'gentle expression', Cromwell remarks on its 'excellent beauty' and 'rosy cheeks', and Cranmer on its youthful and now peaceful appearance. Such rejuvenation and beautification was a traditional feature of hagiographical narrative, the bodily incorruption indicating a sign of sainthood and immortality. However, here such meaning is subverted by the king, Cromwell, and Cranmer, who attribute the restored youth and beauty to the fact that death has robbed Fisher of his 'venom', 'hatred' and 'savage malice'. The vehemence of their comments is reinforced a few lines further on when Bryan tells Henry, 'Queen Anne, your Majesty, greatly desires to see this head into which the poison wholly poured itself' ('Regina, princeps, Anna cernere percupit | Totus quod in se virus effudit caput', ll. 1930-1931). This request appears to echo Salome's desire to see the head of John the Baptist, especially as Henry was often likened to Herod by Catholic writers; moreover, Harpsfield had explicitly made a comparison between Anne and Salome in his Treatise of Marriage, and Stapleton had implicitly done so in his Life of More. ${ }^{13}$ Henry continues in violent vein with his threats to bring the Catholic North of England to submis-

13 See Highley, '“A Pestilent and Seditious Book”', pp. 157-158. 
sion if they refuse to recognize him as head of the English church. The last words pronounced on stage reinforce the violence and negativity that have prevailed throughout the scene. Madness and Heresy, the evil personifications who prophesy the future, deliver curses on England, foretelling 'civil strife' and a 'conquered faith' through images of death and hell. In 1617-1618 when Roffensis appears to have been written, the winds of war were becoming manifest and within the year what we now call The Thirty Years' War had begun.

\section{Conclusion}

Of these martyr plays performed at the English College in Rome, Roffensis ends the most negatively, but all three are strong indictments of the power of the monarch. Henry viII is the dominant example of secular power but also of heresy and evil. He destroys his best councilors and ignores his responsibility to rule justly. He is perceived as a tyrant who follows his own selfish desires as he deserts his queen and invites an insidious whore to his bed, and who is responsible for the martyrdom of two men loyal to the Catholic faith. The two other King Henrys represented, who lived more than three centuries earlier, are similarly responsible for the martyrdom of a man of great faith, Thomas Becket, and for the pursuit of a struggle between secular and religious power. All these rulers abuse their powers and ignore their duty to Christ and the true church according to Catholic belief, and from the perspective of the seminary training of priests for the English mission, namely to return England to the Roman fold, the succession of rulers following Henry vinI, with the exception of Mary, continue in their evil ways. At the English College in Rome Henry viII could be criticized more overtly than on the stage in England itself, witness the differences between Thomas Morus and Sir Thomas More, which certainly has more to do with the ideological and geographical distance between Rome and England than with the different languages, Latin and English. The college had been a center of plots against the rulers of England, especially against Elizabeth, ${ }^{14}$ and the three plays give evidence of this role. However, this is not the only context. The plays may also figure in the conflict between papal authority and secular power that was still ongoing when the plays were performed; at least, that is especially true for the second play, Thomas Cantuariensis, which can

14 See James C. Briant, Tudor Drama and Religious Controversy (Macon, GA: Mercer University Press, 1984), p. 37. Briant mentions an interesting account of life at the English College by Anthony Munday: The English Romayne Lyfe (1582). 
be contextualized in the delicate succession of King James. Thus, these three 'school plays', preserved in manuscript, but read, staged and seen at the English College, conveyed serious political-religious messages.

\section{Further Reading}

Allen, William, A true sincere and modest defence of English Catholiques that suffer for their faith both at home and abrode: against a false, seditious and slaunderous libel intituled: The execution of iustice in England. Wherein is declared, how vniustlie the Protestants doe charge Catholiques with treason ([Rouen: Fr. Parson's press, 1584]).

Bloemendal, Jan, and Howard B. Norland (eds.), Neo-Latin Drama and Theatre in Early Modern Europe (Leiden and Boston: Brill, 2013) Drama and Theatre in Early Modern Europe, 3 .

Briet Monta, Susannah, Martyrdom and Literature in Early Modern England (Cambridge: Cambridge University Press, 2005).

Covington, Sarah, The Trail of Martyrdom: Persecution and Resistance in SixteenthCentury England (Notre Dame, Indiana: University of Notre Dame Press, 2003).

Dillon, Anne, The Construction of Martyrdom in the English Catholic Community, 15531603 (Aldershot: Ashgate, 2003).

Marotti, Arthur, 'Manuscript Transmission and the Catholic Martyrdom Account in Early Modern England', in Arthur F. Marotti and Michael D. Bristol (eds.), Print, Manuscript, and Performance: The Changing Relations of the Media in Early Modern England (Columbus, Ohio: Ohio State University Press, 2000).

McCabe, William H., An Introduction to the Jesuit Theater, ed. by Louis J. Oldani (St. Louis, Missouri: The Institute of Jesuit Sources, 1983).

Middleton, Paul, Martyrdom: A Guide for the Perplexed (London and New York: T. and T. Clark, 2011).

Persons, Robert, The Jesuits memorial, for the intended reformation of England, under their first popish prince: Published from the copy that was presented to the late King James II. With an introduction, and some animadversions, by Edward Gee ... (London: Richard Chiswell, 1690).

Petti, Anthony G. 'Richard Verstegan and Catholic Martyrologies of the Later Elizabethan Period', Recusant History 5 (1959), 78-81.

Simons, Joseph. Jesuit Theatre Englished: Five Tragedies of Joseph Simons, transl. by L.J. Oldani and P.C. Fisher (St. Louis, Missouri: Institute of Jesuit Sources, 1989). 